\title{
Christian W. Troll - Dialogue and Difference: Clarity in Christian-Muslim Relations
}

transl. David Marshall (Maryknoll NY: Orbis Books, 2009), 182 pp.

ISBN: 978-1570758560. US\$25.12 [original German title: Unterscheiden um zu klären. Orientierung im christlich-islamischen Dialog (Freiburg im Breisgau: Herder Verlag, 2008)]

Christoph Marcinkowski International Institute of Advanced Islamic Studies (IAIS) Malaysia

It is certainly not easy these days to break a lance for dialogue with the scandalridden Catholic Church: ...paedophile 'predator priests', seemingly roaming freely through the Western (and developing) world; rampant moral decay among large segments of the Roman Catholic priesthood, while - at the same time - continuous preaching to other cultures and civilisations of the merits of Christian virtues; the alleged beating up of innocent orphan children, sometimes to unconsciousness, by a certain former German bishop who had been accused of lying under oath and invoking the name of God when questioned by legal authorities; the attempts to hush up such crimes; the financial (not to mention moral) bankruptcy of entire dioceses throughout the United States due to the compensation claims running into millions of US dollars by tens of thousands of victims - the list could be continued endlessly...

Such (and other even more disturbing) 'revelations' have certainly also affected the way people of all faiths are now looking at Pope Benedict XVI and his approach to interfaith relations. For many people (this reviewer included) what is at stake is the credibility of the Roman Catholic Church as one of the leading moral forces in this world. One might well argue that Christianity - and its Roman Catholic version in particular - would do well to start first to clear up the rather serious issues that lay at its own doorstep. Such a disastrous scenario does not make matters any easier for those who have been professionally involved for decades in the Catholic-Muslim dialogue industry - among them Christian W. Troll, a German Roman Catholic priest, a member of the Jesuit Order, and the author of the book here under review.

Troll - one of the Vatican's foremost authorities in the field of contemporary Christian-Muslim relations - visited IAIS Malaysia in November 2008, where he delivered a lecture that was subsequently published by the Institute in its Occasional Papers Series. ${ }^{1}$ For decades, Troll, who is personally known to this reviewer as a person of integrity, has publicly taken position on topics and debates concerning the world's two largest faiths - Islam and Christianity. He is currently Honorary Professor of the Philosophical-Theological University of Sankt Georgen at Frankfurt am Main. From 1993 to 2005, he was a member of the sub-commission for CatholicMuslim relations, which is part of the Pontifical Council for Inter-Religious Dialogue 
(PCID). Since 1999, he has also been a member of the German Bishops Conference's sub-commission for inter-religious dialogue. He is thus a senior figure in today's Christian-Muslim dialogue industry. Troll therefore knows what he is talking about when he focuses in this volume on the different dimensions of Christian-Muslim dialogue. According to him, clarification and distinction through gathering central figures and collating teachings of the respective religion are essential. Necessary for a meaningful dialogue between Christians and Muslims is, from Troll's perspective, also an assessment of the essential aspects of the Muslim faith under the criteria of Christian theology in which he is located. He tries to make out what elements are shared by Christianity and Islam and where they differ from each other. Troll argues that in order to enter into a meaningful dialogue it would be necessary to mark out and understand differences not only in theology but also in worldview.

The first 70 years of Troll's biography were somewhat intertwined: After five years of studies - Bonn, Tübingen, Beirut, London - the five main stations of his activities before Frankfurt were New Delhi, Birmingham, Rome, Ankara and Berlin. It appears that each of these places has shaped the author. Troll knows life among Muslims in majority as well as diaspora situations. He is also well acquainted with the forms of life and ways of interpretation of Islam in various social and cultural contexts. Moreover, he knows Catholic theology as a university professor and as a living reality. He finally knows the legitimate and/or exaggerated concerns of the German public spheres. These experiences seem to have amalgamated somehow in Troll's basic attitude.

The original German version of this book was published in 2008 (Freiburg im Breisgau: Herder Verlag) under the title Unterscheiden um zu klären. Orientierung im christlich-islamischen Dialog, which could be translated as 'Distinguishing in order to clarify: Orientation in Christian-Muslim dialogue'. 'Distinguishing', for Troll, still means to add certain differentiations that have so far been missed out. It is thus the opposite of 'political correctness', or of what has become known recently in German as Kuscheldialog, literally 'cuddle dialogue', thus a dialogue which tries to make everybody involved to 'feel good' by leaving out core areas of dissent. 'Distinguishing' is therefore also always readiness to distinguish.

Troll's book revolves around the Christian-Muslim encounter in two major runs. The first (more descriptive) part deals with the dimensions of dialogue. It locates the dialogue industry within the context of Germany, as well as of the contemporary Muslim world at large, and maps the main issues and problems. The second, somewhat more critical, part 'exposes', from the perspective of Troll, currently fashionable unification motifs, such as the 'Abrahamic heritage' as mere 'eyewash'. One might bring Troll's distinction of the Jewish, Christian and Muslim views of Abraham to the formula 'departure, dawn and friction'. In addition to this, 'clarification' is also a demand that is concerned with daily affairs. In 
this manner, the procedure of 'distinguishing' emerges as some sort of 'peaceful culture of debate' that is carried by 'critical sympathy', as a kind of sobriety that allows us to make out common objectives without the blurring of differences. This is certainly something else than ideological multiculturalism or enforced assimilation. Troll's target description can therefore be summarised as 'fair and peaceful mutuality' (Konvivenz).

The publication of Troll's writings of the last two decades or so - first by Herder Verlag in Germany and then in Maryknoll's English translation here under review - is certainly to be welcomed. This is because the author has provided us with the tools that he had been able to prepare for himself in the course of his own life, tools that allow us to accept more meaningfully the challenges that are often posed by interfaith 'insecurities' - even if those tools had been created by someone who might ascribe to a different religious or philosophical persuasion (that is, different from that of many of the readers of this journal). Troll's main tool may be referred to as 'inter-religious distinguishing'. What does he mean by that? That an honest debate can lead to unexpected results. However, there is hardly any alternative to this open-ended attitude. After all, someone who wants solutions must want dialogue as well.

In closing then, we can say that Troll's approach of 'distinguishing' - that is, of not avoiding key areas of difference between Islam and Christianity - makes this book an important contribution, even for those who hail from a different religious tradition. It is hoped that in the not too distant future Muslim scholars too will be able to reciprocate with a book that follows a similar approach - this time, however, from the perspective of their own faith and tradition. This is because only an open and honest approach can make Muslim-Christian dialogue a meaningful reality.

\section{Note}

1. Christian W. Troll SJ, "Dialogue as Encounter in Faith: Problems and Prospects", IAIS Malaysia Occasional Paper Series, no. 3 (Kuala Lumpur: International Institute of Advance Islamic Studies (IAIS) Malaysia, 2009). 